YURIJ P. PERELYGIN', MARIAN J. JASKUŁA ${ }^{2 *}$ IRINA V. RASHEVSKAYA

${ }^{1}$ Penza State University, Penza, Russia

${ }^{2}$ Jagiellonian University, Cracow, Poland
Scientific paper

ISSN 0351-9465, E-ISSN 2466-2585

UDC: $66.065: 669.014 .6 .7$

doi:10.5937/ZasMat1602314P

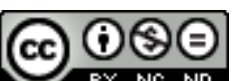

Zastita Materijala 57 (2)

314 - 317 (2016)

\title{
Calculation of equilibria in the solution above the precipitate of a hydroxide of a metal capable forming hydroxycomplexes
}

\begin{abstract}
The simple equations for the determination of $\mathrm{pH}$ range in which the precipitation with maximum amount of the sparingly soluble metal hydroxide and the minimum concentration of the metal in the solution occur were derived.
\end{abstract}

Keywords: metal hydroxide precipitate, metal hydrocomplexes, equilibria, wastewater treatment.

\section{INTRODUCTION}

Precipitation of metals as hydroxides is widely used in hydrometallurgy [1], analytical chemistry [2] and especially in wastewater treatment $[3,4]$ where many various practical modifications are proposed [5-8].

Many of heavy metal ions create not only insoluble hydroxides but soluble hydroxycomplexes too, and phase equilibria in the solution must be taken into account and they are intensively investtigated [9]. An useful example present the paper of Jin et al. [10] where a method for calculation of ion distribution in reaction systems formed hydroxides was proposed, but it is relatively sophisticated.

In our previous paper [11] the equations for the determination of initial and final $\mathrm{pHs}$ of metal hydroxide precipitation as well as dissolution, due to the formation of hydroxycomplexes were derived.

It is a particular theoretical and practical interest to obtain an equation showing the dependence of the fraction of the metal ion forming a poorly soluble hydroxide and capable to dissolve through the formation of hydroxocomplexes, as well as an equation expressing the total metal ion concentration and its hydroxycomplexes over the sediment of metal hydroxide sludge, on the $\mathrm{pH}$ of the solution.

${ }^{*}$ Corresponding author: Marian J. Jaskula

E-mail: jaskula@chemia.uj.edu.pl

Paper received: 10. 03. 2016.

Paper accepted: 20.04.2016.

Paper is available on the website: www.idk.org.rs/journal

\section{THE PROBLEM STATEMENT}

In the solution containing the ligand $\left(\mathrm{OH}^{-}\right)$, capable of forming one complex with the metal ion $\left[\mathrm{M}(\mathrm{OH})_{y}^{(-y+x)}\right]$ and the precipitate of metal hydroxide $\left(\mathrm{M}(\mathrm{OH})_{x}\right)$ two equilibria are established:

$$
\begin{aligned}
& \mathrm{M}(\mathrm{OH})_{x} \leftrightarrow M^{+x}+x \mathrm{OH}^{-} \\
& \text {and }\left[\mathrm{M}(\mathrm{OH})_{y}^{(-y+x)}\right] \leftrightarrow M^{+x}+y \mathrm{OH}^{-},
\end{aligned}
$$

which are described, according to [2], by the equations:

$$
\begin{aligned}
& K_{s p}=\left[\mathrm{M}^{+x}\right]\left[\mathrm{OH}^{-}\right]^{x} \\
& K=\frac{\left[\mathrm{M}^{+x}\right]\left[\mathrm{OH}^{-}\right]^{y}}{\left[\mathrm{M}(\mathrm{OH})_{y}^{(-y+x)}\right]}
\end{aligned}
$$

where: $\mathrm{K}_{\mathrm{sp}}$ - hydroxide solubility product, $\mathrm{K}$ - instability constant of a hydroxy-complex, $x$ - valence of the metal, and $y$ - the coordination number of the metal.

The metal ion concentrations $\left[M^{+x}\right]$ are equal to each other according to reactions (a) and (b). The solution of the equations (1) and (2) with respect to $\left[\mathrm{M}(\mathrm{OH})_{y}^{(-y+x)}\right]$, leads to the following expression when the ionic product of water $\left(\mathrm{K}_{\mathrm{w}}=\right.$ $\left.\left[\mathrm{H}^{+}\right]\left[\mathrm{OH}^{-}\right]\right)$is taken into account.

$$
\left[\mathrm{M}(\mathrm{OH})_{y}^{(-y+x)}\right]=\frac{K_{s p}\left(K_{w}\right)^{y-x}}{\left[H^{+}\right]^{y-x} K} .
$$

According to the material balance the sum of the amount of the metal in the precipitate, as a hydroxide $(m / M)$, in the solution in the form of 
hydroxide complexes $\left[\mathrm{M}(\mathrm{OH})_{y}^{-y+x}\right]$ and as the free ion $\left[M^{+x}\right]$ is equal to the initial amount of metal in solution:

$$
c_{M} V=\frac{m}{M}+\left[M(O H)_{y}^{-y+x}\right] V+\left[M^{+x}\right] V
$$

where $\mathrm{V}$ represents the solution volume, $\mathrm{m}$ and $\mathrm{M}$ are the mass of sediment and molar mass of the metal hydroxide, respectively, and $\mathrm{C}_{\mathrm{M}}$ is the initial metal ion concentration in the solution ( $\mathrm{mol} / \mathrm{L})$.

Dividing both sides of the last equation by the initial amount of metal in solution $\left(c_{M} V\right)$, and introducing concentration of hydroxycomplexes calculated from equation (3) as well as metal ion concentration calculated from equation (1) gives the following equation:

$$
\alpha=1-\frac{K_{s p}\left(K_{w}\right)^{y-x}}{\left[H^{+}\right]^{y-x} K c_{M}}-\frac{K_{s p}\left[H^{+}\right]^{x}}{\left(K_{w}\right)^{x} c_{M}}
$$

which allows calculation of the relative fraction of metal $\left(\alpha=m / c_{M} V M\right)$ present in the hydroxide precipitate.

It is quite simple to obtain the equation determining the total concentration of metal ions and its hydroxycomplex (c, mol/L) over the hydroxide precipitate from equation (5):

$$
c=\frac{K_{s p}\left(K_{w}\right)^{y-x}}{\left[H^{+}\right]^{y-x} K}+\frac{K_{s p}\left[H^{+}\right]^{x}}{\left(K_{w}\right)^{x}}
$$

Taking into account that $\left[\mathrm{H}^{+}\right]=10^{-\mathrm{pH}}$ the last two equations can be rewritten as follows:

$$
\begin{aligned}
& \alpha=1-\frac{K_{s p}\left(K_{w}\right)^{y-x}}{10^{-p H(y-x)} K c_{M}}-\frac{K_{s p} 10^{-p H x}}{\left(K_{w}\right)^{x} c_{m}} \\
& c=\frac{K_{s p}\left(K_{w}\right)^{y-x}}{10^{-p H(y-x)} K}+\frac{K_{s p} 10^{-p H x}}{\left(K_{w}\right)^{x}}
\end{aligned}
$$

Equations (7) and (8) describe, respectively, the dependence of the relative fraction of the metal hydroxide or total metal ion concentration over the deposit (free ions and hydroxycomplexes) on the $\mathrm{pH}$ of solution, that previously $[11,12]$ was described by two equations. These equations are valid only under the condition that $m / M \leq c_{M} V$.

As follows from equation (7), the relative fraction of the metal ion, present in a hydroxide precipitate is dependent on the type of metal ion, the initial concentration and the $\mathrm{pH}$ of the solution, which was noted in [13].

The first term of equation (8) allows to calculate the concentration of the metal ion, and the second term the concentration of its hydroxycomplex depending on the $\mathrm{pH}$ of the solution.

\section{EXAMPLE 1: A SOLUTION CONTAINING ALUMINUM IONS}

For the solution containing aluminum ion, which forms one complex compound $\left[\mathrm{Al}(\mathrm{OH})_{4}^{-}\right]$only the relative fraction of aluminum hydroxide containning in the precipitate will be given by the following equation

$$
\alpha=1-\frac{K_{s p}}{c_{M} 10^{3 p H}\left(K_{w}\right)^{3}}-\frac{K_{s p} K_{w} 10^{p H}}{K c_{M}}
$$

From this expression it follows that the relative fraction of aluminum hydroxide at a constant $\mathrm{pH}$ increases as the initial concentration of the aluminum salt in solution increases, and depends strongly on $\mathrm{pH}$.

The validity of this equation is confirmed by the fact that the calculated values of $\mathrm{pH}$ at the start of aluminum hydroxide precipitation and at the complete dissolution of the precipitate practically coincide with the values determined experimentally. Thus, when the initial aluminum salt concentration was $0.01 \mathrm{~mol} / \mathrm{L}$ the $\mathrm{pH}$ of start of precipitation onset and complete dissolution of the aluminum hydroxide respectively determined experimentally are equal to 4.0 and 10.8 [13], and the last equation gives the values of 3.52 and 10.78 .

Figure 1 shows the dependence of the relative fraction of aluminum hydroxide on the $\mathrm{pH}$ of the solution at the concentration of aluminum sulfate 3 * $10^{-4} \mathrm{~mol} / \mathrm{L}(100 \mathrm{mg} / \mathrm{L})$.

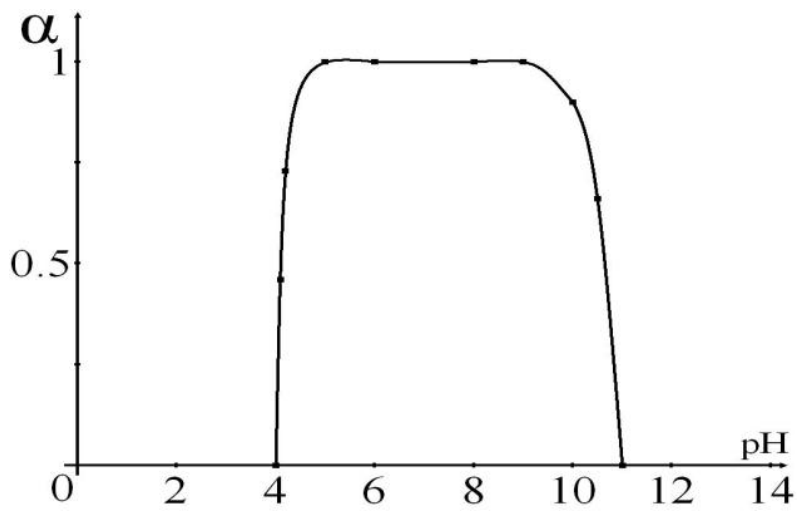

Figure 1 - The relative fraction of the aluminum hydroxide $(\alpha)$ depending on the $\mathrm{pH}$ of the solution.

The figure shows that almost all aluminum in the solution is present in the form of a poorly soluble hydroxide in the $\mathrm{pH}$ range from 5 to 10 , what practically coincides with the $\mathrm{pH}$ values recommended in [14-16]. The optimum $\mathrm{pH}$ value for each water source is usually established experimentally, but these calculations reduce the time of necessary measurements.

The data of solubility product of the aluminum hydroxide and instability constant of its hydroxyl- 
complexes were taken from [13], and, the $\mathrm{pH}$ value at which $10 \%$ of initial amount of metal ions was precipitated [12] was defined as the beginning of precipitation.

The differences in the data of solubility product given in the literature may cause the differences in the results. For example, the use of the value of $\mathrm{K}_{\mathrm{sp}}$ equal to $3.210^{-32}$ [17], leads to the $\mathrm{pH}$ of precipitate beginning equal to 4.27 .

\section{EXAMPLE 2: A SOLUTION CONTAINING ZINC AND CHROMIUM IONS}

Considering that zinc and chromium ions form hydroxides $\mathrm{Zn}(\mathrm{OH})_{2}$ and $\mathrm{Cr}(\mathrm{OH})_{3}$, as well as the hydroxycomplexes $\left[\mathrm{Zn}(\mathrm{OH})_{4}^{-2}\right]$ and $\left[\mathrm{Cr}(\mathrm{OH})_{4}^{-3}\right]$ respectively, the last two equations for solutions containing these metals, can be written as follows:

$$
\begin{aligned}
& \alpha_{Z n}=1-\frac{K_{s p, Z n}\left(K_{w}\right)^{2} 10^{2 p H}}{K_{Z n} c_{Z n}}-\frac{K_{s p, Z n}}{10^{2 p H}\left(K_{w}\right)^{2} c_{Z n}} \\
& \alpha_{C r}=1-\frac{K_{s p, C r}\left(K_{w}\right) 10^{p H}}{K_{C r} c_{C r}}-\frac{K_{s p, C r}}{10^{3 p H}\left(K_{w}\right)^{3} c_{C r}} \\
& c_{1}=\frac{K_{s p, Z n}\left(K_{w}\right)^{2} 10^{2 p H}}{K_{Z n}}+\frac{K_{s p, Z n}}{10^{2 p H}\left(K_{w}\right)^{2}} \\
& c_{2}=\frac{K_{s p, C r}\left(K_{w}\right) 10^{p H}}{K_{C r}}+\frac{K_{s p, C r}}{10^{3 p H}\left(K_{w}\right)^{3}}
\end{aligned}
$$

where: $c_{1}$ is the total concentration of zinc ions and its hydroxycomplex above the precipitate of zinc hydroxide, $c_{2}$ the total concentration of chromium ion and hydroxycomplexes above the precipitate chromium hydroxide, $K_{C r}$ and $K_{z n}, K_{\mathrm{sp}, \mathrm{Cr}}$ and $\mathrm{K}_{\mathrm{sp}, \mathrm{Zn}}{ }^{-}$ the instability constants of hydroxycomplexes of chromium and zinc, and the solubility products of chromium and zinc hydroxide, respectively, which values were taken from $[13,17]$.

For practical purposes, it is the most important to know the $\mathrm{pH}$ value at which the total metal ion concentration present in the form of an ion and a soluble hydroxycomplex reaches the maximum allowable concentration in the wastewater (MAC $\mathrm{mg} / \mathrm{L}$ ), i.e. $\left[M(O H)_{y}^{(-y+x)}\right]=[M A C] / A x 1000$ (where A - atomic mass of metal). In this case, the last two equations take the form

$$
\begin{aligned}
& \frac{\left[M A C_{Z n}\right]}{65,4 \bullet 1000}=\frac{K_{s p, Z n}\left(K_{w}\right)^{2} 10^{2 p H}}{K_{Z n}}+\frac{K_{s p, Z n}}{10^{2 p H}\left(K_{w}\right)^{2}} \\
& \frac{\left[M A C_{C r}\right]}{52 \bullet 1000}=\frac{K_{s p, C r}\left(K_{w}\right) 10^{p H}}{K_{C r}}+\frac{K_{s p, C r}}{10^{3 p H}\left(K_{w}\right)^{3}}
\end{aligned}
$$

The solution of these equations for zinc is a range of $\mathrm{pH}$ values from 9.15 to 10.3 (the MAC value for zinc is $0.01 \mathrm{mg} / \mathrm{L}$ ), i.e., the precipitation of zinc hydroxide down to the value of MAC occurs in a very narrow $\mathrm{pH}$ range.

Precipitation of the chromium down to the MAC value (MAC for chromium (III) is $0.03 \mathrm{mg} / \mathrm{L}$ ) occurs in a wider range of $\mathrm{pH}$, and namely 6-9.5. As it is shown by calculations performed according to the equations (10) and (11), in these $\mathrm{pH}$ range most complete precipitation of the hydroxides of these metals occurs. The calculated $\mathrm{pH}$ intervals coincide almost exactly with the values given in the literature $[3,13,19-20]$.

When the above mentioned two ions are simultaneously present in the solution, the range of $\mathrm{pH}$, wherein their concentration does not exceed the assigned limits of MAC's becomes more narrow, and is equal to 9.15-9.5.

It should be emphasized that the simultaneous presence of aluminum ions and other metal ions in the solution can lead to the co-precipitation with aluminum hydroxide [14-16], thereby reducing their concentration in water.

\section{CONCLUSIONS}

Equation (7) allows calculation of the $\mathrm{pH}$ range in which the maximum formation of sludge of metal hydroxides occurs, i.e. prevent the ingress of metal ions on urban wastewater treatment plants.

The equation (8) allows determination of the $\mathrm{pH}$ range in which the ion concentrations of metals forming the hydroxycomplexes in the industrial wastewater would be under the value of maximum allowable concentration.

\section{REFERENCES}

[1] G.M. Goldman, A.N. Zelikman (1993) Teoria gidrometalurgicheskich procesov, Metallurgia, Moskva.

[2] A.P. Kreshkov (1965) Osnowy analiticheskoj khimii. Teoreticheskie osnowy. Kachestvennyj analiz, Tom 1, Khimia, Moskva.

[3] V.A. Proskuriakov, L.I. Schmidt (1977) Ochistka stochnyh vod w khimicheskoj promyshlennosti, Khimia, Leningrad.

[4] S.S. Vinogradov (1998) Ekologicheski bezopasnoe galvanicheskoe proizvodstvo, Proizvodstvennoizdatelskoe predprijatie „Globus”, Moskva.

[5] M.D. Machado, E.V. Soares, H.M.V.M. Soares (2011) Selective recovery of chromium, copper, nickel, and zinc from an acid solution using an environmentally friendly process, ENVIRON SCI POLLUT R, 18(8), 1279-1285.

[6] E. R. Christensen, J.T. Delwiche (1982) Removal of heavy metals from electroplating rinsewaters by precipitation, flocculation and ultrafiltration, WATER RES 16(5), 729-737. 
[7] C. Zhu (2002) Estimation of surface precipitation constants for sorption of divalent metals onto hydrous ferric oxide and calcite, CHEM GEOL, 188(1-2), 23-32.

[8] H. Ma, L. Hua, K. Lian, X. Ma (2014) Adsorptive removal of trivalent chromium in aqueous solution using precipitate produced from aluminum tanning wastewater, WATER AIR SOIL POLL 225(5), Article number 1956.

[9] W.L. Marshall (1985) Aqueous inorganic phase equilibria at high temperatures: Some experimental, theoretical, and applied aspects, PURE APPL CHEM, 57(2), 283-301.

[10] Z.-N. Jin, D.-R. Jong, J.-S.Hong, Y.-H.Jong, D.-K. Lu, G.-B. Chen (2013) T NONFERR METAL SOC, 23(12), 3793-3798.

[11] Yu. P. Perelygin (2011) Calculation of a relative fraction of metal ion passed in hydroxy complex depending on $\mathrm{pH}$ of a solution, RUSS $\mathrm{J}$ APPL CHEM+, 84(6), 1073-1074.

[12] Yu. P. Perelygin, I.V. Rashevskaya (2006) On the term "pH of the precipitation onset of heavy metal hydroxides, RUSS J APPL CHEM+, 79(3), 492-493.
[13] Yu.Yu. Lurie, (1965) Spravochnik po analiticheskoj khimii, Khimia, Moskva.

[14] E.D. Babenko, Ochistka vody koagulantami (1977) Nauka, Moskva.

[15] L.L. Paal, Ja.Ja. Karu, H.A. Mender, B.N. Repin (1994) Spravochnik po ochistke prirodnych i stochnyh vod, p.51-58, Vysshaja Shkola, Moskva.

[16] A.K. Zapolskii, A.A. Baran (1987) Koagulanty i flokulanty w procesach ochistki vody, Khimia, Leningrad.

[17] P.A. Lidin, L.L. Andreeva, B.A. Molochko (2006) Konstanty neorganicheskih veshchestv: spravochnik, Drofa, Moskva.

[18] S.V. Pestrikov, N.N. Krasnogorskaia, G.N. Sapozhnikova, O.Yu. Isaeva (2006) Snizhenie ekologicheskoj opasnostii metallosoderzhashchih stochnyh vod, Ufimskij Gosudarstvennyj aviacionnyj tehnicheskij universitet, Ufa.

[19] V.M. Talanov, G.M. Zhitnyj (2007) Ionnye ravnovesija w vodnyh rostvorach, Izdatelsvtvo „Akademia Estvoznanija” (http://www.rae.ru/ monographs/).

IZVOD

\section{ODREĐIVANJE RAVNOTEŽE U RASTVORU IZNAD TALOGA METAL HIDROKSIDA PRI FORMIRANJU KOMPLEKSA HIDROKSIDA}

$U$ ovom radu prikazane su jednostavne jednačine za određivanje oblasti $p H$ u kojima će se formirati maksimalna količina taloga metal hidroksida pri minimalnoj koncentraciji metalnih jona $u$ rastvoru.

Ključne reči: talog metal hidroksida, metalni hidro kompleksi, ravnoteža, tretman otpadnih voda.

Naučni rad

Rad primljen: 10. 03. 2016.

Rad prihvaćen: 20. 04. 2016.

Rad je dostupan na sajtu: www.idk.org.rs/casopis 